\author{
Agata ŻochowsKA ${ }^{1}$
}

\title{
Nowe warunki udzielania wsparcia finansowego grupom producentów rolnych w ramach Wspólnej Polityki Rolnej
}

\section{Uwagi wstępne}

Grupa producentów rolnych w świetle przepisów unijnych jest preferowaną formą prowadzenia działalności rolniczej. Unia Europejska zauważyła, że współdziałanie producentów rolnych pozytywnie wpływa na ich usytuowanie w rzeczywistości gospodarczej, między innymi poprzez obniżanie kosztów produkcji rolniczej, dostosowanie się do wymogów rynków zagranicznych oraz uzyskiwanie wyższych kwot za wyprodukowane płody rolne. Zauważono także, że zespołowe formy współpracy producentów rolnych pozytywnie wpływają na gospodarkę Unii Europejskiej - realizując tym samym cele określone w Traktacie Rzymskim, zapewniając np. stabilizację rynków czy bezpieczeństwo dostaw oraz koncentrację produkcji. ${ }^{2} \mathrm{~W}$ polskiej rzeczywistości gospodarczej także zauważalna jest tendencja zgodnie, z którą coraz bardziej wzrasta zainteresowanie wskazaną powyżej formą współdziałania producentów rolnych. ${ }^{3}$

Unia Europejska zauważając istotny wpływ grup producentów rolnych na rozwój i stabilizację rolnictwa europejskiego, wprowadziła szereg instrumentów zachęcających indywidualnych producentów rolnych do współdziałania. Jednym z nich, było udzielenie na rzecz powstałej grupy - bezpośredniego wsparcia finansowego. Udzielona pomoc finansowa przybrała częściową formę refundacji kosztów kwalifikowanych poniesionych na rzecz grupy producentów rolnych, przez jej poszczególnych członków. Do kosztów powyższych można zaliczyć m.in. koszty budowy, modernizacji lub przebudowy budynków produkcyjnych lub magazynowych stanowiących infrastrukturę zakładów przetwórstwa, czy koszty zakupu lub leasingu ma-

A. Jurcewicz, P. Popardowski, J. Zięba, Prawne podstawy wspólnej polityki rolnej, [w:] Prawo i polityka Unii Europejskiej, A. Jurcewicz (red.), Warszawa 2010, s. 14-15, A. Jurcewicz, Traktatowe podstawy unijnego prawa rolnego w świetle orzecznictwa. Zagadnienia wybrane, Warszawa 2012. 
szyn lub urządzeń do przetwarzania, magazynowania lub przygotowania produktów do sprzedaży. ${ }^{4}$ Od 2000 roku wielkość udzielonego wsparcia, warunki i tryb wypłaty, a także cele przyznanej pomocy finansowej, zmieniały swoją treść w zależności od przepisów obowiązującej ustawy oraz treści szeregu jej aktów wykonawczych.

Aktualnie, tryb i warunki przyznawania wsparcia finansowego grupom producentów rolnych w ramach Wspólnej Polityki Rolnej na lata 2014-2020 uregulowane są w rozporządzeniu Ministra Rolnictwa i Rozwoju Wsi z dnia 2 sierpnia 2016 r. w sprawie szczegółowych warunków i trybu przyznawania, wypłaty oraz zwrotu pomocy finansowej w ramach działania „Tworzenie grup producentów i organizacji producentów" objętego Programem Rozwoju Obszarów Wiejskich na lata 20142020, zwanego dalej „rozporządzeniem”. ${ }^{5}$ Rozporządzenie powyższe stanowi akt wykonawczy ustawy z dnia 20 lutego 2015 r. o wspieraniu rozwoju obszarów wiejskich z udziałem środków Europejskiego Funduszu Rolnego na rzecz Rozwoju Obszarów Wiejskich w ramach Programu Rozwoju Obszarów Wiejskich na lata 2014$2020 .^{6}$

Wsparcie finansowe grup producentów rolnych nie zawsze znajdowało swoje źródło ze środków pochodzących z budżetu Unii Europejskiej, przeznaczonych na finansowanie wspólnej polityki rolnej. Instytucja grupy producentów rolnych została wprowadzona do polskiego systemu prawa ustawą z dnia 15 września 2000 r. o grupach producentów rolnych i ich związkach oraz o zmianie innych ustaw. ${ }^{7} \mathrm{~W}$ pierwszych latach istnienia instytucji grupy producentów rolnych, przepisy ustanawiające zasady i tryb przyznawania im pomocy finansowej uregulowane były wprost $\mathrm{w}$ ustawie. Od 20 października 2000 r. do 30 kwietnia 2004 r. wsparcie finansowe grup przeznaczone było na założenie i wsparcie ich działalności administracyjnej w okresie pierwszych pięciu lat od dnia wydania decyzji administracyjnej stwierdzającej spełnienie przez grupę warunków określonych w ustawie. Pomoc finansowa określana była ryczałtowo, uzależniona od udokumentowanych rocznych przychodów ze sprzedaży produktów, z uwagi na które grupa została utworzona i wytworzonych w gospodarstwach jej członków, przy czym pomoc ta nie mogła przekroczyć kosztu założenia grupy i rocznego kosztu jej działalności administracyjnej. Wysokość środków na ten cel określała ustawa budżetowa. Pomocy finansowej udzielała ARiMR, na wniosek grupy, ze środków przyznanych na ten cel w ustawie budżetowej.

$\mathrm{Z}$ dniem 1 maja 2004 roku, na skutek podpisania w dniu 16 kwietnia 2003 roku tzw. Traktatu akcesyjnego - Rzeczypospolita Polska przystąpiła do Unii Europejskiej. Konsekwencją powyższego było uznanie zasady pierwszeństwa prawa wspól-

\footnotetext{
4 Dostępny w Internecie: <http://www.podrb.pl/przedsiebiorczo/1332-grupy-producenckie.html> (data dostępu: 30.09.2016 r.)

Dz.U. z 2016 r. poz. 1284

Dz.U. z 2015 r. poz. 349.

Dz.U. z 2000 r. Nr 88, poz. 983, z późn. zm.
} 
notowego przed prawem państwa członkowskiego, przy czym zasada ta nie miała charakteru bezwzględnie obowiązującej. Polski Trybunał Konstytucyjny potwierdził, iż o ile prawo wspólnotowe może mieć pierwszeństwo przed ustawami prawa krajowego, o tyle nie oznacza to, że ma automatycznie pierwszeństwo także przed Konstytucją. ${ }^{8} \mathrm{~W}$ ślad za powyższym, w dniu 1 maja 2004 roku weszła w życie ustawa z dnia 28 listopada 2003 r. o wspieraniu rozwoju obszarów wiejskich ze środków pochodzących z Sekcji Gwarancji Europejskiego Funduszu Orientacji i Gwarancji Rolnej $^{9}$ - która zmieniła źródło finansowania grup producentów rolnych z budżetu krajowego na środki finansowe pochodzące z Unii Europejskiej. Tryb i warunki przyznawania pomocy finansowej zostały określone wprost w treści ustawy. Pomocy finansowej udzielała ARiMR, na wniosek grupy producentów rolnych, ze środków przyznanych na ten cel w budżecie Unii Europejskiej, do wysokości limitu stanowiącego równowartość w złotych kwoty euro określonej w planie na wspieranie grup producentów rolnych. Wspomniana ustawa, przepisem art. 12, uchyliła w ustawie o grupach producentów rolnych i ich związkach artykuły regulujące pomoc finansową grupom, zaznaczając jednocześnie, iż grupy producentów rolnych, które zostały wpisane do rejestru grup do dnia 30 kwietnia 2004 r. otrzymują pomoc finansową na dotychczasowych zasadach.

Kontynuacja wspólnotowej pomocy finansowej grupom producentów rolnych podtrzymana została w ustawie z dnia 7 marca 2007 r. o wspieraniu rozwoju obszarów wiejskich z udziałem środków Europejskiego Funduszu Rolnego na rzecz Rozwoju Obszarów Wiejskich w ramach Programu Rozwoju Obszarów Wiejskich na lata 2007-2013. ${ }^{10}$ Wskazana regulacja określiła zasady przyznawania pomocy finansowej zgodnie z programem określonym w rozporządzeniu Rady (WE) nr 1698/2005 z dnia 20 września 2005 r. w sprawie wsparcia rozwoju obszarów wiejskich przez Europejski Fundusz Rolny na rzecz Rozwoju Obszarów Wiejskich (EFRROW). ${ }^{11}$ Szczegółowy tryb i warunki przyznawania pomocy finansowej grupom producentów rolnych ustalił Minister Rolnictwa i Rozwoju Wsi rozporządzeniem z dnia 20 kwietnia 2007 r. w sprawie szczegółowych warunków i trybu przyznawania pomocy finansowej w ramach działania „Grupy producentów rolnych” objętej Programem Rozwoju Obszarów Wiejskich na lata 2007-2013. ${ }^{12}$

W zakresie obowiązującego Programu Rozwoju Obszarów Wiejskich na lata 2014-2020, w ramach działania „Tworzenie grup producentów i organizacji producentów" funkcjonuje rozporządzenie określające szczegółowe warunki i tryb przyznawania, wypłaty oraz zwrotu pomocy finansowej z dnia 2 sierpnia $2016 \mathrm{r}$. Akt powyższy stanowi kontynuację wsparcia finansowego grup w ramach działa-

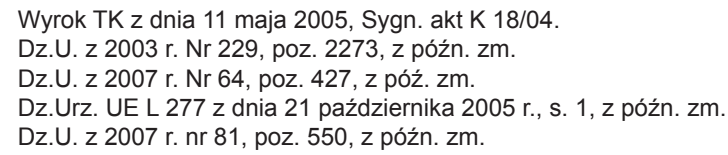


nia „Grupy producentów rolnych” objętych Programem Rozwoju Obszarów Wiejskich na lata 2007-2013. Rozporządzenie uwzględnia szereg zmian legislacyjnych, powstałych na skutek wejścia w życie ustawy z dnia 11 września 2015 roku o zmianie ustawy o grupach producentów rolnych i ich związkach oraz o zmianie innych ustaw oraz ustawy o wspieraniu rozwoju obszarów wiejskich z udziałem środków Europejskiego Funduszu Rolnego na rzecz Rozwoju Obszarów Wiejskich w ramach Programu Rozwoju Obszarów Wiejskich na lata 2014-2020. ${ }^{13}$ Jednocześnie zaproponowane rozwiązanie pozwoliło na dostosowanie się do zasad i warunków udzielania pomocy finansowej grupom producentów rolnych określonych w rozporządzeniu Parlamentu Europejskiego i Rady (UE) nr 1305/2013 z dnia 17 grudnia 2013 r. w sprawie wsparcia rozwoju obszarów wiejskich przez Europejski Fundusz Rolny na rzecz Rozwoju Obszarów Wiejskich (EFRROW) i uchylającym rozporządzenie Rady (WE) nr 1698/2005.

\section{Grupa producentów rolnych jako podmiot wsparcia finansowego}

Aktualnie, o pomoc finansową z Europejskiego Funduszu Rolnego w ramach działania „tworzenie grup producentów i organizacji producentów”, zgodnie z rozporządzeniem z dnia 2 sierpnia 2016 r., mogą ubiegać się grupy producentów rolnych, w skład których wchodzą wyłącznie osoby fizyczne. Wyłączone z prawa składania wniosków są grupy producentów rolnych utworzone w związku z hodowlą drobiu żywego (bez względu na wiek) oraz produkcją mięsa lub jadalnego podrobia drobiowego: świeżego, chłodzonego, mrożonego. § 2 rozporządzenia stanowi swoiste novum, ponieważ do tej pory beneficjentami unijnej pomocy finansowej były grupy producentów rolnych, w skład których wchodziły osoby fizyczne, osoby prawne oraz jednostki organizacyjne nie posiadające osobowości prawnej. Od 19 sierpnia 2016 roku, brzmienie $§ 2$ rozporządzenia jasno obrazuje, iż celem ustawodawcy jest udzielenie pomocy finansowej indywidualnemu producentowi rolnemu rozumianemu jako osoba fizyczna, co stanowi odstąpienie od uregulowań ustawy z dnia 18 grudnia 2003 r. o krajowym systemie ewidencji producentów, ewidencji gospodarstw rolnych oraz ewidencji wniosków o przyznanie płatności ${ }^{14} \mathrm{w}$ zakresie definicji legalnej producenta rolnego. W doktrynie prawa zdążono podnieść, iż wprowadzenie takiego rozwiązania z jednej strony skutecznie wyeliminuje podmioty stricte nastawione na zysk, z drugiej strony przyjęte rozwiązanie może okazać się krzywdzące wobec rolniczych spółdzielni produkcyjnych, które tworzyły grupy producentów rolnych z rolnikami, bądź innymi RSP. ${ }^{15}$

Dz.U. z 2015 r. poz. 1888.

Dz.U. z 2004 r. nr 10, poz. 76.

A. Suchoń, Grupy i organizacje producentów rolnych wobec wyzwań Wspólnej Polityki 2014-2020, „Studia luridica Agraria" 2015, nr XIII. 
Pamiętać należy, iż zgodnie z ustawą o grupach producentów rolnych, po jej nowelizacji z dnia 11 września 2015 roku, od dnia 17 listopada 2015 roku za grupę producentów rolnych uznajemy osoby fizyczne, jednostki organizacyjne nieposiadające osobowości prawnej oraz osoby prawne, które w ramach działalności rolniczej prowadzą gospodarstwo rolne w rozumieniu przepisów o podatku rolnym lub dział specjalny produkcji rolnej. Przy czym, działalność rolnicza, o której mowa powyżej, oznacza działalność rolniczą w rozumieniu art. 4 ust. 1 lit. c pkt i rozporządzenia Parlamentu Europejskiego i Rady (UE) nr 1307/2013 z dnia 17 grudnia 2013 r. tj. produkcję, hodowlę lub uprawę produktów rolnych, w tym zbiory, dojenie, hodowlę zwierząt oraz utrzymywanie zwierząt do celów gospodarskich czy utrzymywanie użytków rolnych w stanie, dzięki któremu nadają się one do wypasu lub uprawy, bez konieczności podejmowania działań przygotowawczych wykraczających poza zwykłe metody rolnicze i zwykły sprzęt rolniczy, w oparciu o kryteria określone przez państwa członkowskie na podstawie ram ustanowionych przez Komisję. Producent rolny, aby móc stać się członkiem grupy producentów rolnych, rozumianą powyżej działalność rolniczą musi prowadzić w gospodarstwie rolnym o łącznej powierzchni przekraczającej 1 ha lub 1 ha przeliczeniowego, stanowiących jego własność lub znajdujących się w jego posiadaniu. Przy czym, ustawodawca ustanowił możliwość posiadania gospodarstwa rolnego nie tylko przez osobę fizyczną, ale także przez osobę prawną oraz jednostkę organizacyjną, w tym spółkę nieposiadającą osobowości prawnej.

Powyższa analiza przepisów określających legalną, ustawową definicją grupy producentów rolnych zawartą w ustawie o grupach producentów rolnych z dnia 15 września 2000 roku, ${ }^{16}$ pozwala na stwierdzenie, iż w rozporządzeniu Ministra Rolnictwa i Rozwoju Wsi z dnia 2 sierpnia 2016 r. - dokonano dużego zawężenia podmiotowego potencjalnych beneficjentów wsparcia finansowego w ramach działania „tworzenia grup producentów i organizacji producentów”. Przypomnieć należy, iż omawiane rozporządzenie stanowi akt wykonawczy do ustawy z dnia 20 lutego 2015 r. o wspieraniu rozwoju obszarów wiejskich z udziałem środków Europejskiego Funduszu Rolnego, która wprost w art. 14 stanowi iż: „Pomoc jest przyznawana osobie fizycznej, osobie prawnej lub jednostce organizacyjnej nieposiadającej osobowości prawnej, jeżeli są spełnione warunki przyznania pomocy określone w przepisach, o których mowa w art. 1 pkt 1 , w przepisach ustawy oraz w przepisach wydanych na podstawie art. 45 ust. 1 pkt 1". Abstrahując zatem od konkretnych warunków, wspomniana ustawa wprost wymienia katalog potencjalnych beneficjentów programu Rozwoju Obszarów Wiejskich, którymi są osoby fizyczne, osoby prawne oraz jednostki organizacyjne nieposiadające osobowości prawnej. W związku z powyższym, biorąc pod uwagę główny cel utworzenia aktu wykonawczego w postaci rozporządzenia, którym jest wykonanie celów ustawy, dokonany zabieg ogranicze- 
nia podmiotowego należy ocenić negatywnie, bowiem uniemożliwia on wykorzystanie ustawowo nadanych uprawnień osobom prawnym i jednostkom nieposiadającym osobowości prawnej.

Dodatkowo, pomoc finansowa objęta Programem Rozwoju Obszarów Wiejskich na lata 2014-2020 ograniczona została w zakresie kręgu potencjalnych beneficjentów - wyłącznie do grup producentów rolnych uznanych nie wcześniej niż w dniu 1 stycznia 2014 roku. Oznacza to zatem, że grupa producentów rolnych zarejestrowana do 31 grudnia 2013 roku, pomimo spełnienia wszystkich warunków formalnych programu Rozwoju Obszarów Wiejskich na lata 2014-2020, pomocy finansowej nie uzyska. Nadto, wsparcia finansowego nie uzyska grupa producentów rolnych, w skład której wchodzi członek będący już beneficjentem pomocy finansowej z Programu Obszarów Wiejskich w latach 2007-2013. Powyższa, negatywna przesłanka uzyskania pomocy finansowej, nie jest związana tylko i wyłącznie z dofinansowywaniem grup producentów rolnych. Rozszerza się ona także na inne działania z Europejskiego Funduszu Rolnego, tj. tworzenie i rozwój mikroprzedsiębiorstw czy zwiększanie wartości dodatniej podstawowej produkcji rolnej i leśnej. Powyższe prowadzi do wniosku, iż wyłączenie możliwości ubiegania się o pomoc finansową przez uznane przed dniem 1 stycznia 2014 roku grupy producentów rolnych uniemożliwia im realizację ustawowo zakreślonych celów, tj. ustanowienia wspólnych zasad dotyczących informacji o produkcji ze szczególnym uwzględnieniem zbiorów i dostępności produktów rolnych czy rozwijania umiejętności biznesowych, marketingowych oraz organizowania i ułatwiania procesów wprowadzania innowacji, a także ochrony środowiska naturalnego.

Kontynuując, aktualnie pomoc finansowa udzielana w ramach wsparcia „tworzenie grup producentów i organizacji producentów” obwarowana jest szeregiem ograniczeń. Porównując wymogi potencjalnego kontrahenta pomocy finansowej zakreślone we wcześniejszych uregulowaniach, z prawem obecnie obowiązującym, wskazuję, iż jedynym niezmienionym wymogiem wsparcia finansowego pozostaje - obowiązek posiadania numeru identyfikacyjnego nadanego w trybie przepisów o krajowym systemie ewidencji producentów, ewidencji gospodarstw rolnych oraz ewidencji wniosków o przyznanie płatności. ${ }^{17}$ Drugim wymogiem, który został pozostawiony w ramach nowego rozporządzenia, jest obowiązek posiadania siedziby grupy na terytorium Rzeczypospolitej Polskiej, a także prowadzenie na jej terytorium produkcji produktu lub grupy produktów, ze względu na które grupa została uznana - przy czym prowadzenie produkcji obowiązuje każdego z członków tej grupy. Dotychczasowe uregulowania stanowiły jedynie, iż grupa wpisana do rejestru grup producentów rolnych, ma prowadzić działalność na terytorium Rzeczypospolitej Polskiej, nie precyzując tym samym podmiotu objętego dyspozycją normy. 
Nowe warunki udzielania wsparcia finansowego grupom producentów rolnych...

Nowe warunki, niezbędne do uzyskania pomocy finansowej przez grupę producentów rolnych z Europejskiego Funduszu Rolnego wymienione zostały w § 3 rozporządzenia z dnia 2 sierpnia 2016 roku. Zakwalifikować do nich należy:

1. Uznanie grupy producentów rolnych przez właściwego ze względu na miejsce siedziby grupy dyrektora oddziału terenowego Agencji Rynku Rolnego.

2. Działanie grupy jako przedsiębiorcy prowadzącego mikro, małe lub średnie przedsiębiorstwo w rozumieniu załącznika I do rozporządzenia Komisji (UE) nr 651/2014 z dnia 17 czerwca 2014 r. uznającego niektóre rodzaje pomocy za zgodne z rynkiem wewnętrznym w zastosowaniu art. 107 i 108 Traktatu. ${ }^{18}$

3. Sprawdzenie i wykluczenie stanu, w którym w skład grupy wchodzą członkowie będący producentami jednego produktu lub grupy produktów, którzy byli członkami grupy producentów rolnych, utworzonej ze względu na ten sam produkt, którym przyznano i wypłacono pomoc na rozpoczęcie działalności ze środków Unii Europejskiej po dniu 1 maja 2004 r.

4. Spełnienie warunku, przez każdego z członków grupy producentów rolnych, polegającego na:

a. Przyznaniu płatności na podstawie przepisów o płatnościach w ramach systemów wsparcia bezpośredniego w roku uznania grupy lub przynajmniej raz w ciągu ostatnich 2 lat poprzedzających rok uznania grupy w przypadku grupy uznanej ze względu na produkt lub grupę produktów roślinnych, z wyłączeniem producentów prowadzących działy specjalne produkcji rolnej, lub,

b. Posiadaniu zwierząt gospodarskich objętych obowiązkiem zgłoszenia do rejestru zwierząt gospodarskich oznakowanych i siedzib stad tych zwierząt, ze względu na które grupa została uznana, przynajmniej w roku poprzedzającym rok uznania grupy, lub,

c. Prowadzeniu działów specjalnych produkcji rolnej przynajmniej w roku poprzedzającym rok uznania grupy - w przypadku grupy uznanej ze względu na produkt lub grupę produktów w ramach działu specjalnego produkcji rolnej, lub,

d. Prowadzeniu produkcji produktów lub grupy produktów, ze względu na które grupa została uznana, innych niż produkty lub grupy produktów wymienione $\mathrm{w}$ lit. a i b, oraz produkty lub grupy produktów w ramach działu specjalnego produkcji rolnej, przynajmniej w roku poprzedzającym rok uznania grupy. 
Dokonując analizy nowych przepisów prawnych określających uprawnionego do wsparcia finansowego przyznawanego w ramach działania „tworzenia grup producentów i organizacji producentów" podkreślić należy, iż wsparcie skierowano do indywidualnych osób fizycznych, będących producentami rolnymi, współdziałających razem $w$ ramach sformalizowanej grupy. Ustawodawca dofinansowuje podmioty działające zgodnie z planem biznesowym, które dążą do realizacji wspólnej polityki rolnej poprzez zwiększenie konkurencyjności czy wprowadzenie innowacyjności. Preferowaną grupą producentów rolnych - w świetle nowego brzmienia rozporządzenia - staje się instytucja, w składzie której poszczególni członkowie grupy producentów rolnych nigdy nie korzystali przy rozpoczęciu działalności ze środków Unii Europejskiej po dniu 1 maja 2004 r.

Zaznaczenia wymaga, że wszystkie wskazane w § 3 rozporządzenia wymogi muszą obligatoryjnie zostać spełnione przez potencjalnych beneficjentów wsparcia finansowego. Wniosek powyższy wyciągnąć należy wprost z konstrukcji przepisu. Wyjątkiem, od powyższej zasady, jest $§ 3$ ust. 5 rozporządzenia, zgodnie z którym ustawodawca zastosował łącznik ,lub”, co wskazuje na możliwość wyboru określonego kryterium.

\section{Składanie wniosków o udzielenie wsparcia finansowego}

Na podstawie art. 5 ust. 3 w zw. z art. 6 ustawy z dnia 20 lutego 2015 r. o wspieraniu rozwoju obszarów wiejskich, Agencja Restrukturyzacji i Modernizacji Rolnictwa pełni funkcję agencji płatniczej w zakresie przyznawania, wypłaty i zwrotu pomocy finansowej. ARiMR przede wszystkim przyjmuje walor instytucji pośredniczącej pomiędzy beneficjentem pomocy unijnej a instytucją zarządzającą wspieranie rozwoju obszarów wiejskich w ramach programu, tj. ministrem właściwym do spraw rozwoju wsi. Nadto, ustawowym ${ }^{19}$ zadaniem ARiMR jest wspieranie powstawania i rozwoju grup producentów rolnych i ich związków.

Wniosek o przyznanie pomocy finansowej grupa producentów rolnych składa do dyrektora oddziału regionalnego ARiMR właściwego ze względu na siedzibę grupy. W strukturze Agencja Restrukturyzacji i Modernizacji Rolnictwa wydzieliła Centralę, 16 Oddziałów Regionalnych oraz 314 Biur Powiatowych. ${ }^{20}$ Wniosek o przyznanie pomocy złożony przesyłką rejestrowaną nadaną $\mathrm{w}$ placówce pocztowej operatora wyznaczonego w rozumieniu ustawy z dnia 23 listopada 2012 r. - Prawo pocztowe ${ }^{21}$ najpóźniej w dniu zakończenia terminu składania wniosków, podle-

19 Ustawa z dnia 9 maja 2008 r. o Agencji Restrukturyzacji i Modernizacji Rolnictwa Dz.U. z 2016 r. poz. 1512 j.t. z dnia 20 września 2016 r.

20 Dostępny w Internecie: < http://www.arimr.gov.pl/o-arimr/oddzialy-regionalne.html> (data dostępu: 29.09.2016 r.).

21 Dz.U. z 2016 r. poz. 1113. 
Nowe warunki udzielania wsparcia finansowego grupom producentów rolnych...

ga rozpatrzeniu, jeżeli wpłynie do oddziału regionalnego Agencji najpóźniej 30 dnia od dnia upływu tego terminu.

Prezes Agencji Restrukturyzacji i Modernizacji Rolnictwa podaje do publicznej wiadomości na stronie internetowej administrowanej przez ARiMR, co najmniej w jednym dzienniku o zasięgu krajowym oraz w siedzibie Centrali Agencji i oddziałów regionalnych Agencji, ogłoszenie o naborze wniosków o przyznanie pomocy, nie później niż 30 dni przed dniem planowanego rozpoczęcia terminu składania tych wniosków. Ogłoszenie Prezesa ARiMR zawiera wskazanie dnia rozpoczęcia oraz dnia zakończenia terminu składania wniosków o przyznanie pomocy, przy czym zakreślony termin nie może być krótszy niż 30 dni oraz dłuższy niż 60 dni. W okresie realizacji Programu Rozwoju Obszarów Wiejskich możliwe jest jednokrotne złożenie wniosku, w terminach od dnia uznania grupy do ostatniego dnia terminu wskazanego przez Prezesa ARiMR.

Dnia 30 sierpnia 2016 roku, na podstawie rozporządzenia Ministra Rolnictwa i Rozwoju Wsi z dnia 2 sierpnia 2016 r., Prezes ARiMR podał do publicznej wiadomości termin pierwszego naboru wniosków, który został ogłoszony w okresie od dnia 30 września do dnia 28 listopada 2016 r. ${ }^{22}$

Wniosek o przyznanie pomocy finansowej udzielanej w ramach wsparcia ,tworzenie grup producentów i organizacji producentów" składany jest przez beneficjentów na formularzu. ARiMR udostępnia formularz wniosku o przyznanie pomocy, formularz wniosku o płatność oraz wzory oświadczeń dołączanych do wniosku o przyznanie pomocy lub wniosku o płatność, nie później niż od dnia podania do publicznej wiadomości ogłoszenia Prezesa ARiMR o naborze wniosków o przyznanie pomocy.

Na skutek wejścia w życie rozporządzenia Ministra Rolnictwa i Rozwoju Wsi w sprawie szczegółowych warunków i trybu przyznawania, wypłaty oraz zwrotu pomocy finansowej w ramach działania ,Tworzenie grup producentów i organizacji producentów" objętego Programem Rozwoju Obszarów Wiejskich na lata 2014-2020, liczba załączników do przedmiotowego wniosku wzrosła kilkukrotnie. Obligatoryjną treść wniosku stanowią informacje doprecyzowujące dane grupy producentów rolnych, tj. numer identyfikacyjny, nazwa i siedziba grupy, dane osób upoważnionych do reprezentowania, data i numer decyzji o wpisaniu grupy do reje$\mathrm{stru}^{23}$ oraz nazwa produktu lub grupy produktów, ze względu na które grupa została utworzona. Rozporządzenie w $§ 6$ wskazuje wprost listę niezbędnych załączników wniosku, przy czym novum stanowi szereg oświadczeń grupy, w tym:

Dostępny w Internecie: <http://www.arimr.gov.pl/pomoc-unijna/prow-2014-2020/tworzenie-grup-producentow-i-organizacji-producentow-dzialanie-9-prow-2014-2020.html> (data dostępu: 05.10.2016 r.).

23 M. Stahl, B. Jaworska-Dębska, Odmowa stwierdzenia spełnienia warunków wpisu i dokonania wpisu do rejestru grup producentów rolnych, [w:] Encyklopedia Samorządu Terytorialnego dla każdego, Warszawa 2011, s. 361. 
1) oświadczenie o planowanej, w każdym z pierwszych 5 lat po uznaniu, wielkości i wartości przychodów ze sprzedaży produktu lub grupy produktów, ze względu na które grupa została uznana, wytworzonych przez jej członków;

2) oświadczenie beneficjenta o planowanej, w kolejnych latach realizacji planu biznesowego, wielkości i wartości przychodów ze sprzedaży produktu lub grupy produktów, ze względu na które został uznany i wytworzonych przez jego członków;

3) oświadczenie grupy oraz jej członków dotyczące spełniania warunków, o których mowa w $§ 3$ ust. 1 pkt 4, 5 i 7 rozporządzenia, a w przypadku grupy utworzonej ze względu na grupę produktów „Ziarno zbóż lub nasiona roślin oleistych”, o której mowa w § 3 ust. 4, również o spełnianiu warunku, o którym mowa w $\S 3$ ust. 4;

4) oświadczenie grupy, że prowadzi jedno z przedsiębiorstw określonych w załączniku I rozporządzenia Komisji (UE) nr 651/2014 z dnia 17 czerwca 2014 r. uznającego niektóre rodzaje pomocy za zgodne z rynkiem wewnętrznym, sporządzone na formularzu udostępnionym przez Agencję;

5) oświadczenie beneficjenta, złożone na podstawie danych rzeczywistych za pełny okres obrachunkowy, potwierdzające, że prowadzi jedno z przedsiębiorstw, o których mowa w załączniku I do rozporządzenia nr 651/2014, sporządzone na formularzu udostępnionym przez Agencję wraz z dokumentami potwierdzającymi ten fakt, za pierwszy rok działalności - w przypadku braku tego potwierdzenia na etapie przyznania pomocy finansowej;

6) oświadczenie grupy, że znane są jej ustawowe obowiązki związane z prowadzeniem, rozliczeniem i postępowaniem kontrolnym udzielonej pomocy finansowej.

Biorąc pod uwagę formę przekazywania i udostępniania informacji, do której grupy producentów rolnych zostały zobligowane - mowa tutaj o oświadczeniach - zastanawiające jest, jak w zakresie składanych oświadczeń kreuje się odpowiedzialność karna składającego oświadczenie? Art. 4 ustawy z dnia 20 lutego 2015 r. o wspieraniu rozwoju obszarów wiejskich, ${ }^{24}$ stanowi, iż: „, zastrzeżeniem zasad i warunków określonych w przepisach, o których mowa w art. 1 pkt 1, do postępowań w sprawach indywidualnych rozstrzyganych $\mathrm{w}$ drodze decyzji administracyjnej stosuje się przepisy ustawy z dnia 14 czerwca 1960 r.- Kodeks postępowania administracyjnego, ${ }^{25}$ chyba że ustawa stanowi inaczej". Dodatkowo, art. 26 ww. ustawy wskazuje wprost, że do działań i poddziałań, o których mowa w art. 3 ust. 1 pkt 3 lit. a, pkt 6 lit. a-c i e oraz pkt 8-12, stosowane są przepisy Kodeksu postępowania administracyjnego. W związku z powyższą analizą przepisów, podstaw odpo- 
Nowe warunki udzielania wsparcia finansowego grupom producentów rolnych...

wiedzialności karnej składającego oświadczenia wobec organu państwowego upatrywać należy na gruncie przepisów prawa administracyjnego. Art. $75 \S 2$ kodeksu postępowania administracyjnego stanowi, iż w sytuacji jeżeli przepis prawa nie wymaga urzędowego potwierdzenia określonych faktów lub stanu prawnego w drodze zaświadczenia właściwego organu administracji, organ administracji publicznej odbiera od strony, na jej wniosek, oświadczenie złożone pod rygorem odpowiedzialności za fałszywe zeznania. O okoliczności tej należy jednak wnioskodawcę pouczyć na podstawie art. $83 \S 3$ k.p.a. W praktyce pracownicy ARiMR nie pouczają potencjalnych beneficjentów ustnie o odpowiedzialności karnej za fałszywe złożenie oświadczenia woli. Rozwiązaniem, które przyjęto jest klauzula zawarta w formularzu wniosku o przyznaniu pomocy finansowej, o następującej treści: ,informacje zawarte we wniosku oraz w jego załącznikach są prawdziwe i zgodne ze stanem prawnym i faktycznym, znane mi są skutki składania fałszywych oświadczeń, wynikające z art. $297 \S 1$ ustawy z dnia 6 czerwca 1997 r. Kodeks karny. ${ }^{26 "}$ "Wprowadzone rozwiązanie ma na celu uniknięcie przekazania środków finansowych do rąk osób nieodpowiednich, tj. nie związanych z produkcją rolniczą, które nie rokują i nie dają podstaw do realizacji celów wspólnej polityki rolnej. Konstrukcja pouczenia o odpowiedzialności karnej zawarta w treści formularza udostępnionego przez ARiMR na oficjalnej stronie internetowej czy w terenowych placówkach organu, daje możliwość zapoznania się z treścią wniosku, co w konsekwencji ma na celu niwelację wyłudzeń finansowych podejmowanych przez fikcyjnych producentów rolnych.

\section{Załatwianie spraw o przyznanie pomocy grupom producentów rolnych}

W świetle obowiązujących przepisów, pomoc finansowa z Europejskiego Funduszu Rolnego przysługuje według kolejności ustalonej przez ARiMR przy zastosowaniu kryteriów wyboru operacji. O kolejności przysługiwania pomocy na działanie „tworzenie grup producentów i organizacji producentów” decyduje suma uzyskanych punktów. Punkty przyznaje dyrektor właściwego oddziału regionalnego ARiMR. Jak wynika wprost z rozporządzenia - w pierwszej kolejności pomoc przysługuje grupom, które uzyskały największą liczbę punktów, przy czym ustawodawca wskazał minimalny próg punktowy, który wynosi 3 punkty. Wniosek grupy producentów rolnych uzyskujący mniej niż minimalną liczbę punktów, nie podlega dalszej weryfikacji, konsekwencją czego dyrektor oddziału regionalnego ARiMR, w drodze decyzji, odmówi przyznania pomocy. Decyzję o takiej samej treści wyda, nie_grup_producentow_i_organizacji_producentow/W_1_327_Wniosek_pomoc_GPR_wer2016_08_26.pdfl> (data dostępu: 05.10.2016 r.). 
w przypadku stwierdzenia barku obligatoryjnych wymagań wniosku wskazanych w $§ 2$ lub $\S 3$ rozporządzenia.

Punktowane kryteria, od których uzależniona jest kolejność przyznawania dofinansowania pieniężnego na rzecz grup producentów rolnych, wskazane są wprost w $§ 7$ ust. 2 rozporządzenia. Dokonując analizy wprowadzonych kryteriów, stwierdzić należy, iż ustawodawca konsekwentnie poprzez instytucję grup producentów rolnych próbuje wpłynąć na strukturę gospodarstw rolnych w Polsce, dążąc do zmniejszenia ich rozdrobnienia, przyznając większą punktację grupie liczącej co najmniej 10 członków - przyznaje 4 punkty, a za każdego kolejnego członka grupy - przyznaje 0,2 punktu. Dodatkowo, jeżeli siedziba grupy znajduje się w powiecie o wysokim rozdrobnieniu agrarnym, w którym udział gospodarstw rolnych, według danych Głównego Urzędu Statystycznego pochodzących z powszechnego spisu rolnego przeprowadzonego w 2010 r., publikowanych na stronie Głównego Urzędu Statystycznego, w przedziale obszarowym 1-15 ha stanowi powyżej $75 \%$ powierzchni użytków rolnych gospodarstw rolnych o powierzchni powyżej 1 ha w powiecie - ARiMR przyznaje 3 punkty; powyżej 50\% do 75\% powierzchni użytków rolnych gospodarstw rolnych o powierzchni powyżej 1 ha w powiecie - ARiMR przyznaje 2 punkty; od $25 \%$ do $50 \%$ powierzchni użytków rolnych gospodarstw rolnych o powierzchni powyżej 1 ha w powiecie - ARiMR przyznaje 1 punkt. Kolejnym celem wprowadzonych zmian jest poprawa konkurencyjności producentów rolnych na rynku zbytu, przy jednoczesnym poszanowaniu środowiska naturalnego. Jeżeli bowiem w planie biznesowym są planowane inwestycje przyczyniające się do innowacyjności - przez wprowadzenie nowych zasad produkcji, procesu lub technologii, odmiennych od obecnie stosowanych, lub zmiana obecnie stosowanych technologii - ARiMR przyznaje beneficjentowi 5 punktów. Identyczną liczbę punktów uzyska grupa producentów rolnych, która w planie biznesowym przeciwdziała zmianom klimatu lub ochrony środowiska - przez stosowanie maszyn, urządzeń, sprzętu lub technologii, ograniczających niekorzystne oddziaływanie na środowisko naturalne lub rozwiązań ograniczających zużycie zasobów, w szczególności wody lub energii. Preferowaną przez ustawodawcę formą prawną prowadzenia grupy producentów rolnych jest spółdzielnia ${ }^{27}$ - ARiMR przyznaje 5 punktów, nie nadając jednocześnie dodatkowej punktacji innym formom prawnym przewidzianym prawem. Niemniej, wskazane kryterium wiąże się jedynie z popularyzacją określonej formy prawnej prowadzenia działalności rolniczej dla grup producentów rolnych. Tak przyjęte rozwiązanie zadziwia, biorąc pod uwagę nowe uregulowania prawne w zakresie zmian ustroju rolnego, które weszły w życie w kwietniu 2016 r. Nowe brzmienie ustawy o kształtowaniu ustroju rolnego z dnia 11 kwietnia 2003 roku $^{28}$ 
Nowe warunki udzielania wsparcia finansowego grupom producentów rolnych...

pozbawia spółdzielnie produkcji rolnej prawa pierwokupu nieruchomości rolnej sprzedawanej przez osobę fizyczną lub osobę prawną inną niż Agencja, pozostawiając takie uprawnienie wyłącznie nabywcy prowadzącemu gospodarstwo rodzinne. Co więcej, nowa ustawa wyłączyła przepisy umożliwiające niestosowanie procedury pierwokupu w stosunku do sprzedaży nieruchomości rolnej stanowiącej wkład gruntowy członka spółdzielni produkcji rolnej na rzecz innego członka tej spółdzielni bądź na rzecz spółdzielni produkcji rolnej. Jak wynika z danych statystycznych, według stanu na dzień 31 grudnia 2014 r. w rejestrach prowadzonych przez marszałków województw wpisanych było 1351 grup producentów rolnych, z czego 65\% prowadzi działalność jako spółki z ograniczoną odpowiedzialnością, $31 \% \mathrm{w}$ formie spółdzielni, 3\% jako zrzeszenia, a $1 \% \mathrm{w}$ formie stowarzyszenia. ${ }^{29}$ Liczba grup producentów rolnych w Polsce wzrasta, jest to konsekwencja popularyzacji tej instytucji przez samorządy rolnicze, instytucje i organy związane z rolnictwem oraz przez samych członków grup producentów rolnych. Podkreślić jednak należy, iż zmiany zachodzące w naszym rolnictwie mają charakter ewolucyjny i uzależnione są w dużej mierze od mechanizmów finansowych, które aktualnie, konsekwentnie są przez Unię Europejską obostrzane. Ustanowione prawem kontrole, nadzór, ograniczenia, kary finansowe - w sposób jednoznaczny wpływają na zmniejszenie zainteresowania producentów rolnych w zakresie współdziałania przy prowadzeniu działalności rolniczej, toteż przyrost liczby grup producentów rolnych w Polsce nie jest duży.

\section{Decyzja o przyznaniu pomocy finansowej oraz decyzja o wypłacie pomocy udzielonej grupom producentów rolnych}

Wydanie decyzji w sprawie przyznania pomocy finansowej grupie producentów rolnych w ramach wspólnej polityki rolnej poprzedzone jest ustaleniem przez Prezesa ARiMR kolejności przysługiwania pomocy - w terminie 90 dni od dnia, w którym upłynął termin składania wniosków. W dalszej kolejności Prezes ARiMR, w terminie 7 dni od dnia ustalenia kolejności przysługiwania pomocy, upublicznia tę informację na stronie internetowej administrowanej przez ARiMR. Po 60 dniach liczonych od upływu wskazanego powyżej terminu, dyrektor oddziału regionalnego ARiMR wydaje decyzję w sprawie przyznania pomocy.

Decyzja w sprawie przyznania pomocy finansowej grupie producentów rolnych ma charakter administracyjno-prawny. Powyższe wynika wprost z art. 26 ustawy z dnia 20 lutego 2015 r., zgodnie z którym do działań polegających na tworzeniu grup producentów i organizacji producentów stosowane są przepisy Kodeksu postępowania administracyjnego. Poza obligatoryjnymi elementami decyzji administracyjnej określonymi w art. 107 Kodeksu postępowania administracyjnego, decyzja 
zawiera pouczenie, zgodnie z którym pomoc finansowa wypłacana jest na wniosek o płatność.

Pomoc finansowa przyznana grupom producentów rolnych wypłacana jest w formie rocznych płatności i obejmuje okresy kolejnych 12 miesięcy prowadzenia działalności przez beneficjenta, licząc od dnia następującego po dniu wydania decyzji o uznaniu. Wniosek o płatność składa się do dyrektora oddziału regionalnego ARiMR właściwego ze względu na siedzibę, w terminie 60 dni od dnia zakończenia każdego kolejnego okresu prowadzenia działalności przez beneficjenta. Ważne jest, ażeby przestrzegać dat składania wniosków; beneficjent, który nie złoży wniosku o płatność za dany okres prowadzenia działalności w określonym czasie, nie może ubiegać się o płatność za ten sam okres w kolejnych latach. Decyzja administracyjna o wypłacie pomocy jest wydawana w terminie 60 dni od skutecznego złożenia wniosku o płatność (szereg załączników wniosku określa $§ 12$ rozporządzenia), przy czym wypłata środków finansowych następuje w terminie 30 dni od dnia, w którym decyzja stała się ostateczna. Rozporządzenie przewiduje możliwość wcześniejszego przelewu pomocy finansowej na rzecz beneficjenta, zwane wyprzedzaniem finansującym. Grupa producentów może złożyć wniosek w oddziale regionalnym ARiMR, w terminie 30 dni od dnia, w którym decyzja przyznająca grupie pomoc finansową stała się ostateczna. Kwota wyprzedzającego finansowania będzie przez ARiMR rozliczana, potrącana w ramach składanych przez grupę wniosków o płatność. ${ }^{30}$

Przyznana pomoc finansowa w ramach instrumentów wsparcia grup producentów rolnych w ramach wspólnej polityki rolnej na lata 2014-2020 będzie realizowana w formie rocznych płatności przez okres pierwszych pięciu lat. $§ 14$ rozporządzenia jasno stanowi, że: ,wysokość pomocy w danym roku prowadzenia działalności przez beneficjenta ustala się na podstawie wartości udokumentowanych rocznych przychodów netto ze sprzedaży produktów lub grupy produktów, ze względu na które grupa została uznana" oraz z analogicznej sprzedaży produktów przetworzonych objętych załącznikiem I do Traktatu o funkcjonowaniu Unii Europejskiej, z wyłączeniem sprzedaży produktów na rzecz członków beneficjenta, współmałżonków członków beneficjenta oraz na rzecz podmiotów powiązanych kapitałowo lub osobowo w sposób bezpośredni lub pośredni z członkiem beneficjenta lub jego współmałżonkiem. Wysokość przyznanego wsparcia finansowego, na zasadach określonych powyżej, wynosić będzie:

1) w pierwszym roku - 10\% przychodów netto,

2) w drugim roku - 8\% przychodów netto,

3) w trzecim roku - 6\% przychodów netto, 
Nowe warunki udzielania wsparcia finansowego grupom producentów rolnych...

4) w czwartym roku - 5\% przychodów netto,

5) w piątym roku - 4\% przychodów netto, przy czym wypłata ostatniej raty wsparcia nastąpi po potwierdzeniu przez ARiMR prawidłowej realizacji planu biznesowego zatwierdzonego zgodnie z ustawą z dnia 15 września $2000 \mathrm{r}$.

Z pomocy określonej w rozporządzeniu Ministra Rolnictwa i Rozwoju Wsi w sprawie szczegółowych warunków i trybu przyznawania, wypłaty oraz zwrotu pomocy finansowej w ramach działania „Tworzenie grup producentów i organizacji producentów" - grupa będzie mogła skorzystać tylko raz w okresie swojej działalności.

\section{Wnioski}

Pomoc finansowa uregulowana w rozporządzeniu Ministra Rolnictwa i Rozwoju Wsi z dnia 2 sierpnia 2016 r. w sprawie szczegółowych warunków i trybu przyznawania, wypłaty oraz zwrotu pomocy finansowej w ramach działania „Tworzenie grup producentów i organizacji producentów”, w porównaniu do poprzedzających rozwiązań prawnych - uległa pozornie drobnej modyfikacji. Dokonane zmiany mogą mieć jednak istotne, realne konsekwencje wpływające na liczbę grup producentów rolnych zakładanych w przyszłości, a także na utrzymanie grup już funkcjonujących. Zmiany polegające na doprecyzowaniu warunków przyznania pomocy finansowej posiadają w porównaniu do dotychczas obowiązujących przepisów - zaostrzony charakter. Po 15 latach udzielania bezpośredniej pomocy finansowej, nasz ustawodawca sformalizował proces udzielania pomocy finansowej grupom, kładąc nacisk na sprawdzenie, gdzie rzeczywiście lokowane będą pieniądze z udzielonej pomocy. Odszedł tym samym od prawdy formalnej, przedstawianej w postaci dokumentacji, a skupił się na realnym wpływie dofinansowań unijnych na gałąź gospodarki, jaką jest rolnictwo. Założeniem ustawodawcy jest ulokowanie środków pieniężnych w rękach producenta rolnego, który jest tylko osobą fizyczną. Nowe uregulowania, wyłączające osoby prawne i jednostki nieposiadające osobowości prawnej z systemu pomocy finansowej w ramach grupy producentów rolnych mogą zmniejszyć liczbę potencjalnych beneficjentów. Niemniej rozwiązania powyższe były konieczne, aby pomoc finansowa trafiała do osób rzeczywiście prowadzących rodzinne gospodarstwa rolne, potrzebujących poprawy sytuacji ekonomicznej. Obecnie obowiązujące warunki i kryteria pomocy finansowej stanowią konsekwencję realizacji celów, jakie postawiono grupom producentów rolnych w ramach Wspólnej Polityki Rolnej na lata 2014-2020; mowa tutaj o efektywności produkcji oraz jej konkurencyjności, wspieraniu działalności rolniczej metodami przyjaznymi środowisku oraz zrównoważony rozwój terytorialny poprzez wspieranie zatrudnienia na terenach wiejskich. Instytucja pomocy finansowej udzielanej 
grupom producentów rolnych, w obowiązującej formie, ma zachęcić także producentów rolnych do zmiany struktur gospodarstw rolnych (odejście od nieefektywnych, rozdrobnionych gospodarstw rolnych), umożliwić im innowacyjne prowadzenie działalności rolniczej, przy pełnym uświadamianiu o koniecznym uszanowaniu i ochronie środowiska naturalnego. Tak skonstruowane cele pomocy finansowej odczytywać można jako zamierzone działanie ustawodawcy, dążącego do kształtowania ustroju rolnego naszego kraju. Oczywistym jest bowiem, że rozdrobnienie agrarne gospodarstw rolnych wciąż pozostaje kluczowym problemem rozwoju wsi i rolnictwa w Polsce. ${ }^{31}$ Przyznanie pomocy finansowej grupom producentów rolnych składających się z osób fizycznych miało na celu rozpoczęcie zmian strukturalnych od gospodarstw najmniejszych. Pomoc finansowa skierowana wyłącznie do osób fizycznych współpracujących przy wspólnym prowadzeniu działalności rolniczej mogłaby wpłynąć na profesjonalizm podmiotu prowadzącego produkcję, sformalizowanie procesu wytwarzania produktu, centralizację sprzedaży produktu czy poprawę efektywności prowadzenia gospodarstw rolnych. Z dokonanych zmian legislacyjnych wywnioskować należy, iż polski ustawodawca pośrednio dąży do zmiany charakteru producenta rolnego, wymagając od niego realizacji cech stricte przypisanych rolnikom prowadzącym gospodarstwa rodzinne, eliminując jednocześnie podmioty nastawione głównie na zysk.

Rządowy projekt ustawy o zmianie ustawy o grupach producentów rolnych i ich związkach oraz o zmianie innych ustaw oraz ustawy o wspieraniu rozwoju obszarów wiejskich z udziałem środków Europejskiego Funduszu Rolnego na rzecz Rozwoju Obszarów Wiejskich w ramach Programu Rozwoju Obszarów Wiejskich na lata 20142020, druk sejmowy $\mathrm{nr} 3836$. 
Nowe warunki udzielania wsparcia finansowego grupom producentów rolnych...

NEW CONDITIONS FOR GRANTING FINANCIAL SUPPORT GROUPS OF AGRICULTURAL PRODUCERS UNDER THE COMMON AGRICULTURAL POLICY

Keywords: Group of agricultural producers, agricultural activity, Common Agricultural Policy

Group of agricultural producers in the EU legislation is the preferred form of running an agricultural activity. The European Union in order to encourage individual farmers to cooperate within a group of agricultural producers introduced a number of incentive instruments, including a system of direct financial assistance to the group. Financial support from the European Union financial resources groups of agricultural producers receive from May 01st, 2004. Currently, the procedure and conditions for financial assistance granted to groups under the Common Agricultural Policy for the years 2014-2020 were largely modified. The above mentioned changes become effective from August 19th, 2016 and are strictly connected with the entry into force of the Regulation of the Minister of Agriculture and Rural Development dated August 02nd, 2016 On Detailed Conditions and Procedure for Granting Payment and Reimbursement of Financial Aid under the Action: „Setting up Producer Groups and Producer Organizations". Under the new rules, financial assistance from the European Union may only receive a group of agricultural producers consisting solely of individuals. The legislator therefore limits the number of potential beneficiaries of aid excluding legal persons and organizational units without legal personality and with legal capacity. Moreover, financial aid would not be granted to a group of agricultural producers which had already received financial assistance from the EU budget funds. In addition, the legislator in the new Regulation introduced a number of criteria on which basis depends the order of granting financial aid. The analysis of the above criteria leads to the conclusion that the financial assistance is directed to the agricultural producer groups operating in the form of a cooperative, including at least 10 members, at the area with high agrarian fragmentation.

Bibliografia:

Gruszewski T.M., Bojar W., Rola grup producentów rolnych w powstawaniu klastrów na terenach wiejskich. Klastry jako narzędzia lokalnego i regionalnego rozwoju gospodarczego, Lublin 2006.

Jurcewicz A., Popardowski P., Zięba P., Prawne podstawy wspólnej polityki rolnej, [w] Prawo i polityka Unii Europejskiej, A. Jurcewicz (red.), Warszawa 2010.

Jurcewicz A., Traktatowe podstawy unijnego prawa rolnego w świetle orzecznictwa. Zagadnienia wybrane, Warszawa 2012. 
Łobos-Kotowska D., Prawna forma organizacji i funkcjonowania grup producentów rolnych, „Studia Iuridica Agraria" 2002, t. III.

Prutis S., Formy organizacyjno-prawne współdziałania producentów rolnych, [w:] P. Czechowski (red.), Prawo Rolne, Warszawa 2015.

Stahl M., Jaworska-Dębska B., Odmowa stwierdzenia spełnienia warunków wpisu i dokonania wpisu do rejestru grup producentów rolnych, [w:] Encyklopedia Samorządu Terytorialnego dla każdego, Warszawa 2011.

Suchoń A., Grupy i organizacje producentów rolnych wobec wyzwań Wspólnej Polityki 2014-2020, „Studia Iuridica Agraria” 2015, nr XIII. 